\title{
Nation-State and its Body-Politics in Kashmir: Representation of State and its Structural violence in Shahnaz Bashir's The Half Mother
}

\author{
Somnath Bandoghati
}

Junior Research Fellow, Department of English, Banaras Hindu University, Varanasi, Uttar Pradesh, India

Email: $\underline{\text { bdgsomnath@gmail.com }}$

\begin{abstract}
In modern day scenario, State has evolved into nation-state. The sense of belonging to a particular nation makes a particular territory to be governed by a single state. To normalize the governance nation-state strives to create nationalist subject which will do anything but question the sovereignty of the state over the territory. And state's blanket monopoly over the armed forces works as a deterrent for the rebel population. It uses different form of tactics to both exert power and govern. This paper seeks to contextualize state violence in a contemporary award-winning Kashmiri novel The Half Mother: a novel with the critical perspectives of Foucault's 'bio-politic' and 'disciplinary society' and also of Agamben's concept of 'bare life'. 'Bio-politics' is a mechanism through which ordinary human lives are managed and regulated by the existing power system. Agamben further develops the concept and contextualizes it in modern nation-state scenario. This paper closely examines the motifs and symbols deployed in the novel to portray the functioning of state-power during the armed insurgence against which the plot of the novel is set. The paper also argues that the novel is a conscious attempt on the part of the novelist to drive home a specific purpose i.e. building up of a discourse against stateoccupation in the valley. Being true to the convention of 'Resistance literature' in The Half Mother also, the story is relegated to the periphery giving that discourse-formation the centre state, the characters remain flat and static and serve as puppet in the hands of its creator.
\end{abstract}

Keywords-Kashmir, The Half Mother, Violence, Nation-State, Resistance. Bio-politics.

\section{INTRODUCTION}

The modern Nation state has undoubtedly emerged as the only rationality in terms of democratic governance. Originating in North-western Europe, undergoing through a series of societal and political transformation, it has evolved into its present form. Though with the expansion of neo-liberal economy, the capacity of its functioning is increasingly shrinking, State manages to exist in the very psyche of its people through its cunning manoeuvring of state apparatus. The legitimacy of Nation State rests primarily on its claim to minimize violence among the people. The formation of State started with the aim of minimizing violence in everyday life. (Elias 1982). It establishes its legitimacy by disarming the people under its governance .The statesanctioned agencies only gain the legitimacy to have access to violence to settle the issues. There exists a mutual agreement between the people and the state which govern them. It willingly surrenders before the State's sovereignty with the condition of protection from any kind of violence. Voluntary surrender of its subject establishes the moral legitimacy of the State to rule over them, to decide their well-being. Max Weber famously argued that a State might for the time being achieve compliance from 'the motives of pure expediency' or "on a purely customary basis through the fact that the corresponding behaviour has become habitual," but these are "much less stable than which enjoys the prestige of being considered binding, or, as it may be expressed, the prestige of "legitimacy." (Weber 31)"It is . . the capacity of the state to command loyalty - the right to rule-to extract the resources necessary to rule and provide services, to maintain that ess ential element of sovereignty, a monopoly over the legitimate use of force within defined territorial limits, and to operate within the context of a consensus-based political community." (Holsti)So the conflict originates at the moment of seeking legitimacy. "It is a characteristic feature of territorial states, for example, that they claim to enjoy a certain set of moral rights (such as the right to be obeyed or the right to enforce the law) over those residing inside their jurisdictions and claim a separate set of moral rights (such as the right to be free from certain forms of interference) over those residing outside their political boundaries." 
(Leviator3)Though theoretically the state must possess the consent to rule over the subject, in modern Nation-State phenomenon it is the territory which decides the legitimacy of the state. The territory happens to be the real subject, and the people residing in it left as mere variable. The notion of the tacit consent to the authority of a particular State simply by residing in its territory got intellectual currency mainly in the celebrated essay of David Humes "Of the Original Contracts". "We may well assert' Hume contends "that a man, by remaining in a vessel, freely consent to the dominion of the master; though he was carried on board while asleep, and must leap into the ocean, and perish, the moment he leaves her" (Humes 193). A person born into a territory by default becomes the subject of the state authority of that territory. The territorial claim by the state leads it to resort to various means in order to get consent from the inhabitants of that territory sometimes by skilful use of state apparatus and sometimes by coarse means. Hence the genesis of state violence lies mostly in its fear of losing legitimacy to rule which poses a serious threat to its sovereignty over the territory. The centrifugal force which binds the population together is the sense of belonging to the land, a sense of shared brotherhood among the people living in a particular territory. This feeling of brotherhood, i.e. nationalism is the basic condition of formation of any Nation. Benedict Anderson in his path breaking book Imagined Communities has traced how this sense of belonging comes into play. He has shown the historical process of nation formation. Though the concept of nation is a political one, nationalism which creates the foundational stone of nation is mostly sociocultural. The state automatically achieves its legitimacy over the territory if it can create a sense of imagined communities' (Anderson 7) among its people. Thus in modern day scenario, State has evolved into nation-state. The sense of belonging to a particular nation makes a particular territory to be governed by a single state. To normalize the governance nation-state strives to create nationalist subject which will do anything but question the sovereignty of the state over the territory. And state's blanket monopoly over the armed forces works as a deterrent for the rebel population. Nation-state uses different form of tactics to both exert power and govern: political murder and terror orchestrated by its agents, disappearance and torture as terror tactics, genocide, legal erasure, and the purposeful entrenchment of structural inequalities.

\section{Kashmir: An 'Othered' Space within Post-Colonial Nation-State}

As already been discussed it is the sense of belonging which binds the entire territory intact and makes a powerful nation- state. But in several occasions, a part of the 'geo-body' of a particular nation-state pops up as a contested land as the people belonging to that particular part of the territory does not feel oneness with the larger part and denies to be ruled by the existing nation-state or more than one nation-state stake claim to that land. With the birth of two nation-states across religious lines through the gruesome human catastrophe called Partition: India and Pakistan, one such contested land came into existence in South-Asian cartographic horizon, the formerly princely state -Jammu and Kashmir, a place where three nationalist sentiments collide - Indian nationalism with its rallying cry- 'Kashmir is an integral part of India', Pakistani nationalism with its claim for 'Kashmir as an unfinished project' and Kashmiri nationalism often referred to as 'Kashmiriyat'.Competing claims, longings, histories and narratives have turned the once 'Paradise on Earth' into the most militarized zone over the earth.'A nation is a soul, a spiritual principle'. (Anderson 12)Post-colonial Indian nation-state's allround attempt to incorporate Kashmir into its nationscape has proved futile because Kashmiris never feel inclined either towards its soul or its principle. Kashmir's repeated resistance to the Indian-nation state and its archenemy Pakistan's claim over the territory has turned the land into an obsession. "The post-colonial India's obsession with its territory of desire makes the Valley a fetish for the Nation-State."(Kabir 7) As a result Kashmir has turned into an 'other space' in the true sense of the Foucaultdian term. Foucoult in his essay "Of Other Space" has spoken of "counter-sites" in which "all the other real sites that can be found within the culture, are simultaneously represented, contested and inverted."(Foucault 3) The fetish existence of the Valley in the collective psyche of post-colonial India has yielded the land into that 'counter-site', a 'heterotopia', a kind of virtual place with real existence. The persistent elusiveness of the object of collective desire puts question mark on the face of the power of nation-state and the state in turn fantasises its existence only over the occupation of the Valley. Territorial existence of the Valley assumes the foreground eliminating the people living in it. Sovereign power establishes itself through the creation of a political order with the exclusion of bare, human life. ${ }^{1}$ If Kashmir turns to be a fetish to the nation-state, Kashmiris in turn grow a kind of counter-fetish towards the state. The conflict which engulfs the valley frequently is mostly the 
outcome of the nation-state's obsessive desire to occupy the land and resultant collective resistance to this forceful occupation. Sovereign state reserves the power to decide the state of exception where the natural course of law is suspended and State starts exercising its power arbitrarily. That collective resistance by Kashmiris against Stateoccupation which often militant in nature makes the situation close to the 'state of exception', "a kinematic state, an emptiness of law", a kind of Hobbesian state of war where nothing is unjust, people live in constant fear of violent death. In that state of exception, the lives of the people seem to be in the state of Zoe ${ }^{2}$, exposed completely to the whims of state.

\section{The Half Mother: A Textual enactment of Structural violence}

Set against the turbulent decade of 1990 when an armed insurgency rocked the Valley, Sahanzar Bashir's The Half Mother aptly epitomizes Agamben's 'the State of exception.' Born and brought up in Kashmir, Bashir had witnessed the gross horrendous reality which entangled the common Kashmiris, robbed them off their minimum natural life. During 1990's a guerrilla war against Indian government spearheaded by Jammu Kashmir Liberation Front (JKLF) broke out in the Valley throwing the national integrity of India into stake. Many a Kashmiri youth joined JKLF and turned into rebels or terrorists. As happens to every sovereign state, India also came heavily on its insurgents. State resorts to every means to eliminate every single threat to its existence. The last and most dreadful way to do so is unlashing of systematic violence which functions in creating a fearpsychosis among the rebel citizens. To supress the insurgents, it responds by employing a familiar mix of overt application of armed force against crowds and protesters and administrative, policing, and profiling techniques such as nocturnal raids, mass arrests and widespread preventive detention. CRPF, a federal force assisted by its local counterpart, Kashmir police started widespread searches across the valley. During the search operation, the military force allegedly resorted to severe abuses including rape, murder, theft, unwarranted arrest and forced disappearance of innocent youth. The Half Mother is the creative recreation of the bleak darkness which descended over the common Kashmiri people during that era of darkness. Natipura is the place where the narrative of the novel is set. It is like any other Kashmiri village where life goes on with its usual slow pace, males busy in earning their livelihood, women with domestic chores and the children with their study and playing. But in the wake of 1987 , with the failed assembly election of Kashmir, the situation took a drastic turn. The places which were so far favourite for the local children for playing secret games became the hiding place for local political fugitives, the orchards which so far bloomed with only beautiful seasonal flowers turned into the safe harbour for armed militants. All these hidings were accompanied by their resultant hide-outs. The natural easy-going life of Natipura came to a halt with the end of the second chapter of the novel. The rest of the novel is the spectacular representation of structural state violence. Ab Jaan's rhetorical premonition "The war has begun" (Bashir 23) alludes to Hobbesian 'state of war' where "there is so little security of life and property, that all live in constant fear and productive work is pointless"(Hobbes,110). In Hobbes's Leviathan 'state of war' is akin to state of nature which can be minimized only by establishing a sovereign state but here the case is reversed with the nation-state deploying wide-spread violence to secure its sovereignty. The tussle between the government and the insurgents which engulfed the valley during the 1990s and still an everyday reality is depicted in the novel "... two masked men had shot a police constable at point-blank range and run away on their scooter...young boys had begun sneaking into Pakistan to fetch arms and rebel against the government."(Bashir 23) A state can tolerate anything but rebel against its sovereignty. Army is deployed in the locality. Foucault in his Discipline and Punish has elucidated the evolution of military power with the arrival of disciplinary society. In the early seventeenth century, the army signified 'a bodily rhetoric of honour', represented military virtues of pride, strength and valour; but with the development of disciplinary society with state as the main functionary army became an instrumentally regulated 'docile body' which would work as a tool to exert the disciplinary power. The intrusion of military into Natipura threatens the domestic-space of the village. "The children stopped and watched the men(army men) do their strange exercise- no one (in the village) had ever seen bunkers inside the valley".(Bashir 24) The banker is a signifier for state-power, a symbolic manifestation of statesurveillance. The bunker 'nearly blocking' the door of the Joo family to the shrine, and making it almost 'invisible' underlines the encroachment of modern state into the private space of its citizens, it obliquely refers to Foucault's bio-power, the authority of the state to regulate the daily lives of its subjects. The link between the bunker and a surveillance-machine becomes more transparent when the novelist says "the bunker was constructed at an angle that allowed its small window a straight view of the Joe family."(24) The self-respectful, freedom-loving and 
a true patriarch of the Joe family Ab Jaan could make out the far-reaching effect of the newly entered bunker, he was "confused and shivering with both rage and fear."(26) His utter disagreement to the occupation of the private space by the outsider army and the eventual realization of his own helplessness evoked in him simultaneously rage and fear. Ab Jaan, though conscious enough of his own powerlessness could not but protest "the bunker will be a nuisance - you will always be intruding into our homes."(26) With the insurgency intensified, situation deteriorated very fast. "Tears, blood, death and war followed, as did curfews, crackdowns, raids, encounters, killings, bunkers, an exodus of people, burning markets, schools and buildings."(32) In the chapter 5 named "Tempest" hell is let loose by the novelist as it abounds with the organised violence committed by army. Young boys are falling to army bullets, women are beaten up and stripped by the trooper, ripe paddy field is set on fire, houses and shops set ablaze and what not. The rules "governing which human lives count as human and as living, and which do not ... are determined to some degree by the question of when and where a life is grieveable, and correctively, when and where the loss of a life remains ungrievable and unrepresentable"(Butler2006). Kashmiris in the period of insurgency stood ungrievable and thereby did not count as human. They were brutally tortured, thrashed, vanished and killed without any explanation."It is the pro-azadi Kashmiri whose humanity poses a serious threat and must therefore be disappeared from the view."(Misri 3) State seeks to "criminalize their thoughts and bodies, and show them as existing beyond the pale of society and humanity'. Ab Jaan's protest -"what is this? You beat everyone...you burn down our shops, you snatch away our living and now you are torturing us. Don't you have any shame?"(48) poses threat to the state-power and it criminalizes $\mathrm{Ab}$ Jaan's thought first and eliminates his body next. 'Shut up or I will kill you!' Kushwaha threatened."(48) When Ab Jaan dared not to shut up "three bullets were pumped into Ab Jaan. One in the neck. One in the heart. One in the stomach." The army captain's boastful declaration "See what happens when you rebel against us" manifests state's intention of ritualizing punishment.

"Punishment is a ceremonial of Sovereignty; it uses the ritual mark of the vengeance that it applies to the body of the condemned man (le corps du condamne); and it deploys before the eyes of the spectators an effect of terror as intense as it is discontinuous, irregular and always above its own laws, the physical presence of the sovereign and of his power.'(Foucault 130)

Apart from the overt manifestation of terror, state often takes recourse to clandestine form of repression because of its strategic advantage. Enforced disappearance happens to be one such potential tool which simultaneously creates insecurity and fearpsychosis among the disturbing community and conceals or denies the crime to avoid domestic unrest and international scrutiny. Haleema's only son Imran was one of the many victims of forced disappearance during the period of insurgency. Haleema pleaded innocence of her son and begged frantically before the army captain to leave her someone to leave with, but her pleading fell on deaf ear and Imran was picked up. Haleema's journey in search of her son gave the novelist ample chance to lead his readers into the plethora of violence state indulged in during the insurgency. The intensity of it can be grasped from the blatant confession of the police constable "our job is now confined to identifying, carrying, delivering dead-bodies to the families. That is the job of the police now."(63) Haleema ran from one camp to another to get a trace of her son. Hallema epitomises thousands of hapless women who lost their near and dear ones in the whirlwind. "The women of Kashmir are in the tens of thousands of widows and half-widows; wives of killed and disappeared men; as well as mothers and grandmothers of missing children."(Shah,253). As Hallema started visiting the detention camps, she witnessed the corporeal torture which the state inflicted upon the young Kashmiri people, it sent a tremor down to her spine. The young boys who were coming out of Badami Bagh cantonment were bearing on their bodies the visible symbol of state violence. The novelist writes "limbless, fingerless, nail less, hairless, toothless, eyeless, earless, detainees- a variety of wriggling, howling, yowling amputated souls."(80) The 'bare' existence of these "yowling amputated souls" pushes them into "a threshold of in distinction and of passage between animal and man, physisand nomos, exclusion and inclusion" (Agamben105). They are reduced to in Agamben's term 'homo sacer'(sacred man), "who may be killed and yet not sacrificed" (Agamben 8). Identified as 'terrorist' in the eyes of the state, they are robbed of their legal status and they are torturedand, killed yet go unlamented. Agamben suggests that in modern democratic set-up, the political prisoners or the suspected terrorists are placed outside the rule of penal and prison law, in 'camps.' Camp is, Agamben writes, "The most absolute biopolitical space ever to have been realized, in which power confronts nothing but pure life, without any 
mediation. This is why the camp is the very paradigm of political space at the point of which politics becomes biopolitics and homo sacer is virtually confused with the citizen." (171)

\section{CONCLUSION}

TheHalf-Mother is an ambitious project on the part of the novelist to relive the harrowing darkness which engulfed the valley during the insurgency movement in the previous century. But while writing the novel, Bashir consciously set his goal i.e. unravelling the military violence upon the innocent Kashmiris and he used his novel as a means to achieve the end. He has achieved his end at the expense of ambivalence and subtlety which constitute the sole of fiction. While speaking about the role of intellectuals to "... challenge and defeat both an imposed silence and the normalized quite of unseen power...", Edward Said has warned that "...he(the intellectual) is neither a pacifier nor a consensus- builder but someone who is staked on a critical sense of being unwilling to accept easy formulas or readymade clichés..."(Said31) But Bashir resorted to that 'easyformulas or ready-made cliches', the popular narrative of brutal torture. Notwithstanding the tangible reality of army brutality, the relentless state oppression, the story seems to be stale and lifeless, characters throughout the novel remain static and flat. The representation of stateviolence is clichéd and one-sided. In Kashmir, army personals and the insurgents both sin and are sinned, both kill and are killed.The novel lacks this ambivalence and trades on easy and conventional path of black-brushing the army. From the very beginning of the novel, an imposed binary between Indian State with its mainland Indians and Kashmir with its Kashmiris is created and the novelist leaves no stone unturned to widen the schism. Imran wears the badge of 'I $\vee$ Kashmir', AB Jaan informs Haleema that government censoring the BBC, 'Azaadi'isthe only sound in the air,the entire valley is put under curfew to unfurl the national flag on independence day, Haleemafaces ill-treatment in Delhi: all are the novelist's conscious attempt to materialize the binary between 'we' $\&$ 'they'.Barbara Harlow in her critically acclaimed book Resistance Literature, while examining the literary creation, coming out of political and cultural conflict, notes in most cases the creators resisting the controlling agency 'take side', as resistance narrative is "a part of historical process, one which requires 'taking sides."(Harlow 203)The Half Mother can rightly be claimed as a resistance narrative where Bashir does not pretend to be neutral, for him art is not a transcendent means of expression but "an integral part of the ideological foundations of new social order." (Harlow 204)

Notes:

1. Italian philosopher Georgia Agamben in his Home Sacer: Sovereign Power and Bare Life theorizes the concept of bare, human life which is produced in the state of exception, a situation when the normal law functioning in a sovereign state remains suspended. Bare life is not simply outside the law, but in the threshold of exclusion and inclusion.

2. State of Zoe is another concept introduced by Agamben in the same book. Etymologically, the Greek word Zoe means natural reproductive life, opposed to Bios which means 'a qualified form of life', political life. In State of Exception, human beings are considered only as Zoe, i.e. biological beings, devoid of their political status.

\section{REFERENCES}

[1] Agamben, G. Homo sacer: Sovereign power and bare life(D. Heller-Roazen, Trans.).: Stanford University Press. 1998

[2] Anderson Benedict. Imagined Communities: Reflections on the Origins and Spread of Nationalism. Revised edition. Verso, 1991

[3] Bashir, Shahnaz. The Half Mother. Hachette, 2014.

[4] Foucault Michel. Discipline and Punish: The Birth of Prison. Trans. Alan Sheridan. Vintage Books. 1979.

[5] Butler, J.,. Precarious Life: the powers of mourning and violence. Verso 2006

[6] Foucault, Michael, "Of Other Spaces". Diacritics No.16,22-27

[7] Harlow, Barbara. Resistance Literature. Methuen \& co., 1987.

[8] Hume, D.. "Of the Original Contract." In Political Essays, edited by $\mathrm{K}$.

[9] Hakkonssen, Cambridge University Press. 1994

[10] Kabir, Jahanara. territory of Desire. University of Minnesota Press, 2009

[11] Leviator, Allex. Normative Legitimacy and the State. Oxford Handbook Online.

10.1093/oxfordhb/9780199935307.013.131. ( Accessed 08 July, 2019)

[12] Misri, Deepti. Showing humanity: violence and visuality in Kashmir, Cultural Studies, 2019.

[13] Said, Edward. The Public Role of Writers and Intellectuals." The Pubic Intellectual, edited by Helen Small, Blackwell Publishing. 2002

[14] Shah , Fahad. Of Occupation and Resistance: Writings fromKashmir.ChennaiTranquebar,2013

[15] Weber, M. "Politics as a Vocation." In From Max Weber: Essays in Sociology,

[16] edited by H. H. Gerth and C. W. Mills, Oxford University Press. 1946 